Accepted manuscript, final version published in:

Villalba X, Mayol L. Right-dislocation in Catalan: tails, polarity and activation. International Review of Pragmatics. 2013;5(1):87-117.DOI: 10.1163/18773109-13050104

\title{
Right-dislocation in Catalan: tails, polarity and activation*
}

\author{
July 25, 2012
}

\begin{abstract}
While our understanding has grown of the discourse role of rightdislocation $(\mathrm{RD})$, there exists a class of $\mathrm{RD}$ (continuing $\mathrm{RD}$ ) that have proven impervious to any principled analysis, for the role of the dislocate is (apparently) null, given that its referent appears immediately before the RD and, thus, simple pronominalisation should suffice to retrieve it. This paper aims to account for the pragmatic felicity conditions of continuing RD by looking at the role of polarity, an overlooked factor in previous work. Particularly, we will show that a significant amount of continuing RD involve the contradiction of part of the interlocutor's common knowledge. Moreover, we will argue that RD

${ }^{*}$ We are very grateful for comments to an anonymous reviewer and to the audience at the Seminar of the Centre de Lingüística Teòrica of the Universitat Autònoma de Barcelona (December 10th, 2010), where a previous version of this paper was presented. This research has been funded by research projects FFI2011-23356 (Ministerio de Ciencia e Innovación, Spain), 2009SGR1079 (Generalitat de Catalunya), awarded to the UAB, and by a Juan de la Cierva grant (JDC-2009-3922) awarded to the first author.
\end{abstract}


does not have a single discourse function, but several: it can work as

a 'tail' or as an activation mechanism.

Keywords: right-dislocation, information structure, polarity, discourse function

\section{Introduction}

Right-dislocation ( $\mathrm{RD}$, henceforth), illustrated in (1), is a frequent construction in Catalan, whose contribution to the discourse structure has been object of considerable debate: see Vallduví (1992, 5.1.3; 5.3.1), Mayol (2006, 2007), Escandell-Vidal (2009, 856-9), and Villalba (2009, ch. 3). ${ }^{1}$
a. I gosaries? Contra el teu amo? and dare.would.2SG against the your master "What - to the master?"

b. Ja no m'ho és, l'amo: ni mai que ho already not to.me-it is the-master neither never that it hagués sigut. had.would.3SG been "He ain't my master, and I wish he never had been." [Guimerà: p. 181]

However, different studies have focused on partial aspects of the construction and none of them can account for the full range of uses of RD in discourse. Our paper aims to give a complete account of the pragmatic felicity conditions of RDs by looking at the referent of the dislocate and at the role of polarity marking, a factor which had not been considered in previous work. The

\footnotetext{
${ }^{1}$ For the source of the English translations, see 3.1. In all examples, the right-dislocated phrase appears in bold.
} 
empirical basis of our proposal is a corpus study consisting of 257 instances of RDs coming from three literary works, which have been coded according to several variables (see section 3 for details).

In particular, we closely examine the instances in which the role of the dislocate is apparently null, since its referent appears immediately before the RD and, thus, simple pronominalisation should be enough to retrieve the intended antecedent. We call such cases "continuing right-dislocation" (continuing RD), an example of which can be found in (1).

In example (1), one might expect a reply leaving aside the dislocate, as in (2). However, continuing RDs are extremely frequent in our data and, although there is some amount of free variation, this is not always the case and, as we discuss later in the paper, there are many instances of continuing RDs where the right dislocate is necessary and cannot be omitted.
a. I gosaries?
Contra el teu amo? and dare.would.2SG against the your master "What - to the master?"

b. Ja no m'ho és: ni mai que ho hagués already not to.me-it is neither never that it had.would.3SG sigut.

been

"He ain't my master, and I wish he never had been."

Our paper is structured as follows. In section 2 we discuss previous literature on the topic and present the main claims of our proposal. Section 3 contains a description of the data and methods used for the corpus study, and section 4 presents the results of such study. Section 5 analyses different types of RDs, argues for the important role of polarity and adverbials in this construction 
and for the analysis of RD as a complex construction with several discourse functions. Finally, section 6 concludes with some final remarks.

\section{Background}

\subsection{Previous work}

Ziv (1994) and Grosz and Ziv (1998) carried out some pioneering work on the study of the discourse functions of RD in English and Hebrew. They showed (Grosz and Ziv 1998, 296-9) that RD must be distinguished from afterthoughts in that it does not merely have a repair function, but has an organizational function in discourse (contra Geluykens (1987); see also Villalba (2009, ch.2) for Catalan).

According to Grosz and Ziv (1998, 299-302), RDs are felicitous in English when referring (i) to an entity present in the discourse situation but not mentioned (as in example (3) for French) or (ii) to entities textually evoked only when (a) they have been mentioned in discourse, but not recently, as in (4), or (b) the NP adds some attributive meaning (as in (5-b)). Otherwise, RDs are predicted to be unacceptable, as in (6).

(3) Il est beau, ce tableau! it is beautiful this painting "It is beautiful, this painting!" (Lambrecht 1981, ex. 123)

(4) A: I asked you to read this book for today.

B: I know. I tried to very hard, but I was quite busy. Incidentally, it is much too difficult for me, this book. (Ziv 1994, ex. 21) 
(5) I took my dog to the vet yesterday.

a. \#He is getting unaffordable, my dog.

b. He is getting unaffordable, the old beast. (Grosz and Ziv 1998, exs. 17 and 21)

(6) A: Did you see Jack yesterday?

B: \#Yes. He is going to Europe, Jack. (Ziv 1994, ex. 20)

The felicity conditions that Grosz and Ziv identify for English are, however, clearly insufficient for Catalan. RDs in Catalan are felicitous in broader contexts, such as to refer to entities just evoked without adding attributive meaning, as shown by (1) (contra their explicit claim in Grosz and Ziv (1998, $301-2)$.

According to Vallduví (1992, 5.3.1), RDs encode a particular information structure instruction, which he calls "tail". In this approach a sentence S can be informationally divided into a focus and an optional ground, which can be further subdivided into a link and a tail.
a. $\mathrm{S}=\{$ focus, ground $\}$
b. $\quad$ ground $=\{$ link, tail $\}$

Information structure is seen as instructions for the update of information. Focus is the new information carried by a particular sentence or, in other words, the information that the hearer is instructed to enter into her/his knowledge store. In contrast, the ground contains the old information and, in particular, "elements that indicate where and how the information must 
be entered". (Vallduví 1992, 58)

As mentioned, the ground can be divided into a link and a tail. The link points to a specific file card (following Heim's (1983) File Change Semantics terminology) for the entry of $\mathrm{I}_{S}$. The tail further specifies how $\mathrm{I}_{S}$ fits on a given file card: "What the presence of the tail does in a given packaging instruction is alter the nature of $\Phi$ [the focus operator], turning it from a 'retrieve-add' to 'retrieve-substitute'." (Vallduví 1992, 79).

All sentences have a focus, while both elements of the ground are optional. Thus, a sentence may present one of the following structures: link-focus, linkfocus tail, all-focus and focus-tail. The four types are illustrated in (8).

(8) a. Link-focus

Tell me about the people in the White House. Is there anything I should know?

(The president $_{\text {Link }}$ ) (hates CHOCOLATE Focus $_{\text {) }}$.

b. Link-focus-tail

And what about the president? How does he feel about chocolate?

(The president $\left._{\text {Link }}\right)\left(\right.$ HATES $\left._{\text {Focus }}\right)\left(\right.$ (hocolate $\left._{\text {Tail }}\right)$.

c. All-focus

The president has a weakness.

(He hates CHOCOLATE Focus $)$.

d. Focus-tail

You shouldn't have brought chocolates for the president.

$\left(\right.$ He HATES $\left._{\text {Focus }}\right)$ ( chocolate $\left._{\text {Tail }}\right)$. 
According to Vallduví, then, an RD is just a sentence with a tail and, therefore, must encode a substitution instruction.

Let us illustrate this approach with the example (1), repeated below for convenience.
a. I gosaries? Contra el teu amo?
and dare.would.2SG against the your master

"What - to the master?"

b. Ja no m'ho és, l'amo: ni mai que ho already not to.me-it is the-master neither never that it hagués sigut.

had.would been

"He ain't my master, and I wish he never had been." [Guimerà: p. 181]

The first utterance in (9) enters two pieces of information into the link's file card. The link is in this case the speaker's interlocutor, called Xeixa. The two pieces of information entered are the following: $(i)$ the question of whether he would dare to do $y$ against his master, and (ii) the presupposition that Sebastià is Xeixa's master. In the reply, the interlocutor disputes this presupposition by means of an RD: the hearer is instructed to go to Xeixa's file card and substitute the entry master(sebastia,xeixa) for its negation. This process is illustrated below, in $(10) .^{2}$

\footnotetext{
${ }^{2}$ The underlying in a file card entry signals presupposed information.
} 


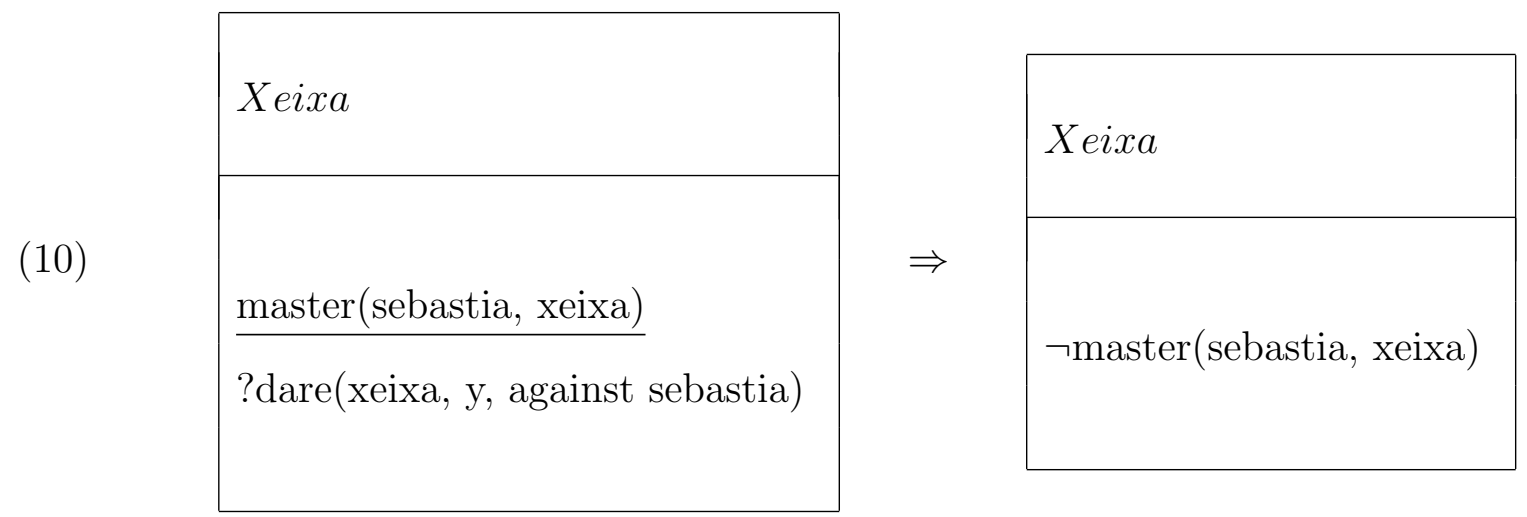

Escandell-Vidal (2009, 856-9) argues against Vallduví in that RDs do not necessarily erase or replace the previously stored information, but add conflicting and maybe unexpected information, which is presented as stronger or as more relevant. According to her, RDs are used to indicate that a new and surprising piece of information should be stored under the label of a highly accessible or familiar entity; that is, they are continuing topics.

a. Balearic (Arxiu, Formentera) (Escandell-Vidal 2009, ex. 54)

A woman is talking about cheese-making and the special container (escudella, 'bowl') with a base (peu, 'base'; lit. 'foot') she uses to make the cheese:

b. ...perquè tenen com un peu que per girar es ... because have.prs.3pl like a base that to turn the formatge va molt bé, i ara no el volen cheese go.prs.3sg very well, and now not it.obj want.prs.3pl fer an aquell peu a ses escudelles make to that base to the bowls '. . because they have a sort of base that is very useful for turning the cheese, but nowadays they don't want to make that base for the bowls anymore' 
The notion of topic has been used in many different ways in the literature. For the purposes of this paper, whenever we use the term 'topic' we mean 'sentence topic': the linguistic information of a sentence tied to the previous discourse (Vallduví (1992, ch. 3) and Givón (1993, 201ff)). For the notion of topic as 'discourse topic' see, among others, Asher and Lascarides (2003) and Roberts (1995).

\subsection{Claims}

Let us present here the main points we will argue for in this paper.

- None of the proposals presented in the previous section can, by itself, account for the behaviour of RDs in Catalan. However, we can take insights from all of them to characterize RD's discourse function.

- RDs frequently act as tails. However, the notion of tail needs be redefined: it is not just a matter of substitution, but also the addition of very specific information, mostly relative to polarity, but also aspect, tense or degree.

- Particularly, we will show that a significant amount of continuing RDs (like (1)) involve the reversal of the polarity of the previous utterance, which results in the negation of a presupposition, and/or the contradiction of part of the interlocutor common knowledge. We will also show that certain temporal and aspectual adverbs can obtain this effect as well.

- Some RDs are not tails, but serve to activate a previously introduced 
referent or a referent inferable from the context (contra Escandell-Vidal (2009, 856-9) not all RDs are continuing topics). That is, RDs can serve to introduce entities which Gundel et al. (1993) would call 'activated': entities which are discourse-old and activated in memory, but not in the current focus of attention.

- From this, we can conclude that RDs do not have a single discourse function but that can accomplish several functions: as tails or as activation topics. Our conclusions are similar to Prince's (1997, 121-134) for left-dislocation in the sense that a particular non-canonical construction may serve different functions.

\section{Data and methods}

\subsection{The corpus}

Corpus instances of RDs were collected from three sources:

- Àngel Guimerà's theatre play Terra Baixa (In Àngel Guimerà, Teatre. MOLC 26, Barcelona: Ed. 62 and "la Caixa". 1998; 23th edition; première 1897) [cited as Guimerà],

- Josep Maria de Sagarra's novel 'Vida privada' (Barcelona, Cercle de Lectors, 2007) [cited as Sagarra], and

- 'El gran somni daurat', Catalan translation of Chester Himes' 'The Big Gold Dream', by Carme Geronès and Carles Urritz (Barcelona, Ed. 62, 1989) [cited as Himes]. 
The works were selected as representative of colloquial register, which is known to favor RD. Terra baixa is plenty of lively dialogues between popular class characters (the main character, Manelic, is an illiterate shepherd), which are intended to reflect popular oral Catalan. Vida privada reflects Barcelona's high class colloquial language (which is exactly the author's own language) before Spanish Civil War (1936-1939). Finally, the translation of Chester Himes' The Big Gold Dream is a nice example of contemporary colloquial Catalan, which accurately reflects the popular lively dialogues of the original. In all the cases, page numbers correspond to the Catalan texts quoted above.

Moreover, the three works cover a large temporal span (almost one century), offering a global picture of the colloquial Catalan of the twentieth century.

As for the English translations, unless otherwise noted, those of Terra baixa come from Martha's of the Lowlands, English version by Owen W. Gillpatrick, available on-line at the Internet Archive http://www.archive.org/). We have respected the text conventions and orthography, but for the sake of clarity, we have regularized thorough the examples the name of the character Xeixa, which Gillpatrick translates as 'Morrucho', following Echegaray's Spanish translation Tierra baja: drama en tres actos y en prosa. In the case of Vida privada, all the translations are by the authors. Finally, the translations of El gran somni daurat are, by a funny turn of events, Chester Himes' originals ( The Big Gold Dream, Pegasus, reprint edition 2008, original 1960), which yielded some spelling mismatching between the glosses (in 
British English) and the translation (in American English).

\subsection{Identification method}

In order to identify instances of RD, the following superficial cues were used:

- right-peripheral element,

- resumptive pronoun

- separation by a comma,

- context.

It must be remarked that, leaving aside the presence of a right-detached element, neither a resumptive pronoun nor a comma were always present. The most obvious case was that of right-dislocated subjects, which lack resumptive pronoun, for Catalan lacks subject clitics (leaving aside the case of indefinite subjects of inaccusative verbs, which may be resumed by means of the partitive clitic en 'of it'). In this case, the context and the presence of a comma were taken as evidence enough for analysing the subject as a right-dislocate, as in the following example:

$$
\begin{aligned}
& \text { PEPA: És que no ens n'amaguem cap, nosaltres, d'any! } \\
& \text { PEPA is that not to.us of.it-hide.1PL none we of-year }
\end{aligned}
$$

"PEPA: 'Cause, we don't hidden our age!" [XV\&LM] [Guimerà: p. $164]$

Here, the subject pronoun appears separated from the core of the sentence by means of a comma, and it is followed by another right-dislocated phrase, 
the NP object (obligatorily preceded by the partitive marker de 'of'), which has stranded the negative polarity item cap 'any/no' in the sentence-final focus position. ${ }^{3}$ It goes without saying that such an identification method showed a certain degree of incertitude, for the use of the comma to separate the right-dislocate wasn't systematic, as the following example shows: ${ }^{4}$

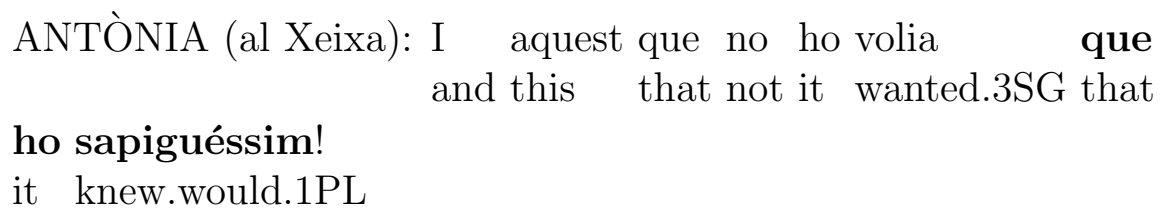

All in all, the number of occurrences identified in the corpus (257) was high enough to consider that the putative instances of misidentification did not affect the generalizations and conclusions of the article in a significant way.

A note on interrogatives It must be highlighted that RDs in interrogative sentences were excluded from the study, because they are subject to different constraints than other type of clauses. As a rule, Catalan interrogative sentences resort to RD where languages like Spanish show inversion

\footnotetext{
${ }^{3}$ Since stressed pronouns can be easily right-dislocated in Catalan, one must reject as false the claim by Ziv (1994, fn. 28) that "the impossibility of stressed pronouns to occur as $\mathrm{NP}$, in $\mathrm{RD}$ is independently predictable on the basis of the unstressed nature of any $\mathrm{NP}$, in RD".

${ }^{4}$ Catalan has three non-personal resumptive pronouns: the partitive clitic en 'of.it', the locative clitic $h i$ 'there', and the neuter clitic $h o$ 'it'. Yet, they cover several functions beyond substitution for partitive, locative, and neuter constituents, respectively. For the sake of readability, the reader should note the following: (i) the partitive clitic en 'of.it' may resume dislocated bare nouns (12) and attributes (25); (ii) the locative clitic $h i$ 'there' may resume locative PPs (21-b) and third person dative complements (36); and (iii) the neuter clitic ho may resume declarative sentences (13), neuter demonstratives or attributes (1).
} 
(Vallduví 2002, 4.4). This fact can be easily appreciated comparing the different solutions for a sample of English questions from Chester Himes' The Big Gold Dream in the Catalan and the Spanish translation (El gran sueño de oro, trans. Carlos Peralta, Barcelona (España), Editorial Bruguera, 1981):

(14) "Do you believe that fairy tale?"

a. Vostès se'l creuen, aquest conte de la vora you.PL self-it believe.3PL this tale of the.FEM side del foc? [Himes: p. 46] of-the fire

b. - ¿Cree usted en ese cuento de hadas? believe.3SG you in this tale of fairies

(15) "Did you see it?"
a. -L'has vist, tu? [Himes: p. 65] him-have.2SG seen you
b. - ¿Lo has visto? him have.2SG seen

(16) "Did you believe her?"
a. -Te l'has creguda, tu? [Himes: p. 164-5] yourself her-have.2SG believed.FEM you
b. - ¿Crees lo que ella dijo? believe.2SG it that she said

In all the cases, the Catalan translation involves a RD, in sharp contrast with the Spanish solution. Note particularly the last two cases, where the pronominal subject appears right-dislocated in Catalan, and is omitted in Spanish. This omission is fully expected given that the pronoun denotes a highly salient referent in subject position (see Ariel (1991) for a proposal 
in which zero anaphora are high accessibility markers and thus, retrieve the most salient antecedents). Henceforth, since interrogatives seem to favour $\mathrm{RD}$ in Catalan, we decided to exclude them from the analysis to avoid distorting data. Eventually, 257 instances of RDs were collected in declarative, exclamative and directive utterances.

\subsection{Variables}

The variables studied were (i) discourse function, (ii) distance between the antecedent and the right-dislocate, and (iii) polarity. All the occurrences in the corpus were coded accordingly.

\section{Discourse function}

The choice of the values for the discourse function was a synthesis of different proposals -particularly Lambrecht (1981, 84ff), Lambrecht (1994, 202-5) and Ashby (1988, 210-224) for French, Grosz and Ziv (1998, 299-305) for English and Hebrew, Mayol (2007, 210-213) for Catalan, Brunetti (2009, sec. 3 and 4.2) for Italian, and Valiouli (1994, 62-67) for Greek-, leaving aside the repair function, because, as argued at length by Grosz and Ziv (1998, 296-9) or Villalba (2009, ch. 3), it is fulfilled by an independent construction -afterthought- with clearly distinctive properties from that of RD (cf. Geluykens (1987)).

First, we considered topic activation: the dislocate recovers referents which are either physically present in the context of utterance (17) or have been introduced previously in the discourse (18), and makes them salient 
enough to be activated as discourse topics (see Lambrecht (1981, 84ff) and Ziv (1994, 639-643) for discussion, and Grosz and Ziv (1998, 299-305) for a formalization in the framework of Centering Theory).

XEIXA garbellant blat. [...] XEIXA: Tant se me'n
XEIXA sifting wheat dóna que quedi net com brut, aquest blat.

matter.3SG that gets clean as dirty this wheat "XEIXA is discovered sifting wheat. XEIXA. What does it matter whether the wheat's clean or whether it ain't clean?" [Guimerà: p. $163]$
a. Els mobles són seus?
the.PL furniture.PL are yours
"You own the furniture, don't you?"

b. Sí.

yes

"Right."

c. Qui és aquesta Alberta Wright? -va deixar anar tot

Who is this Alberta Wright PAST.3SG let go all

d'un plegat el jueu.

of-a together the Jew

"Who is this woman, Alberta Wright?" the Jew threw in suddenly.

d. Ella? és la meva dona -va dir Rufus sense her is the my wife PAST.3SG say Rufus without parpellejar.

blinking

"Her? She's my wife," Rufus said, without batting an eye.

e. Per què no continuava solter? -es queixà el for what not stay.2SG bachelor self complained.3SG the jueu-. és millor.

Jew is better

"Why didn't you stick to being a bachelor?" the Jew com- 
plained. "That was safer."

f. Doncs miri, mestre, aquest cop és diferent -va dir well see.2SG master this time is different PAST.3SG say Rufus-. Els haig de vendre pel compte d'ella, Rufus them have.3SG of sell by.the account of-her els meus mobles.

the.PL my.PL furniture.PL

"Well, you see, daddy-O, this time it's different," Rufus said.

"This time it's on her account that I got to sell my furniture."

[Himes: p. 20-1]

The second value for discourse function is continuation of an active topic. From a purely functional point of view, continuation topics have received no proper account in the literature, for, under standard assumptions, the referent is already an active topic, and one would expect simply omission of the dislocate (see Mayol (2007, 212-3) and Brunetti (2009, sec. 4.2)). ${ }^{5}$ Yet, this quandary is even more apparent in an example like the following, where the same referent appears as a right-dislocate in two consecutive utterances:

$$
\begin{aligned}
& \text { MARTA: Jo no el vui, no, a aquest home! Jo no } \\
& \text { I'haig not him want.1SG not to this man I not } \\
& \text { de voler al Manelic! }
\end{aligned}
$$

him-have.1SG of want to-the Manelic

"I don't want him, this man! I will not want him, Manelic" [Guimerà:

p. 169]

Note for instance that this particular function does not fit what one would

\footnotetext{
${ }^{5}$ The distinction traced here between activation and continuation resembles the distinction between pronouns and definite DPs traced in Vallduví (1992, fn. 49), who builds on previous insights by Chafe (1976) and Prince (1981): "definites trigger an activation of a dormant pre-existent address. Pronouns simply indicate that their referent is in activation at the time of utterance".
} 
expect for a tail, for, in Vallduví's words, "[a] tailful instruction directs the hearer to some entry under a given address and indicates that the focus completes or alters in some way that entry." Vallduví $(1992,80)$. Yet, it is difficult to imagine in which way the second case of RD helps completing or altering the content of the entry for Manelic. A clear indicator of the theoretical difficulty involved is the false prediction made by Ziv (1994, 6401) and Grosz and Ziv $(1998,301)$ that these examples should be impossible altogether.

Notwithstanding, one must note that it has been pointed out in the literature (Valiouli (1994, 62-3), Grosz and Ziv (1998, 302); Mayol (2007, 213)) that the presence of the right-dislocate adds an expressive flavour in these cases -typically, surprise or irritation-, which would suggest that the optionality or superfluousness of the dislocate is more apparent than real. We will turn back to this issue in the discussion section.

Before closing this section, we would like to point out that we stick to the widely held view that right-dislocates must be highly presuppositional, and as a consequence, cannot introduce a new referent into discourse. As Ziv (1994, fn. 27) notes, "RDs cannot be used to introduce discourse-new entities which are not situationally evoked, and even in instances of textually inferred entities, the two seem to abide by somewhat distinct set-inferencing constraints." (similar claims are made in Brunetti (2009, sec. 4.2), Mayol (2007, 210-3) and Villalba $(2011,1952))$. 


\section{Distance}

As complementary of the discourse function, a variable was considered concerning the distance between the dislocate and its antecedent in the discourse, which owes much to Talmy Givón's work on topic continuity (Givón 1983).

The typology was threefold, including local, non-local, and inferable antecedents. The class of local antecedents included all cases of RD with an explicit antecedent in the same or previous utterance:

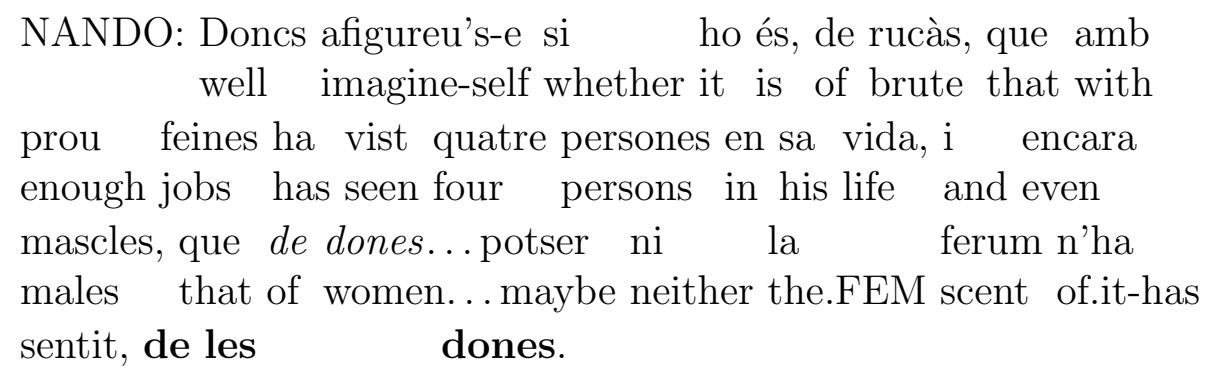

"NANDO: He's a brute, an animal! He's never seen anything in his

life but goats hardly ever a man and a woman Why, he's never laid eyes on one, ..." [Guimerà: p. 168]
a. SEBASTiÀ: Au, Xeixa, a casament.
Come.on Xeixa to ceremony
"SEBASTIÀ: Come on, Xeixa, to the ceremony." [XV]
b. XEIXA: No hi vaig jo, a casament.
not there PAST.1SG I to ceremony
"XEIXA [sullenly]. Because I'm not goin'." [Guimerà: p. 180]

RD was considered as involving a non-local antecedent if an explicit antecedent existed two or more utterances away: 
a. -Resistència a l'autoritat -continua el gras-. Per resistance to the-authority went.on.3SG the fat for què ho has fet, si no tenies culpa? La what it have.2SG done if not had.2SG guilt the.FEM policia és amiga teva.

police is friend your.FEM.

"Resisting arrest," the big cop went on. "Why did you do that if you're not guilty? The police are your friends."

b. El públic acollí aquesta sortida amb una riallada the audience got.3SG this joke with a.FEM laugh totalment justificada, però tant ella com el poli s'ho totally deserved but as she as the cop self-it agafaven de valent.

take of brave

This got a well-deserved laugh from the appreciative audience,

but both she and the cop were in dead earnest.

c. -Que ho sabia jo, que eren polis? -féu ella-. Amb that it know.1SG I that were.2PL cops said she with aquest estrèpit em pensava que havia arribat el this noise to.me thought.1SG that had.3SG came the dia del judici final. Algú m'ha enxampat per day of-the judgement final somebody to.me grabbed.3SG by la cama. Em creia que era el dimoni. the.FEM leg to.me thought.1SG that was the devil Vostè també n'hi oposaria, de resistència, si el you too of.it-there oppose of resistance if the dimoni li estirés la cama el dia del devil to.him pull.would.3SG the.FEM leg the day of-the judici final. [Himes: p. 42]

judgement final

"How did I know you was the cops?" she said. "I heard the noise and thought the judgment day was here; and somebody grabbed me by the legs. I thought it were the devil. You'd resist, too, if the devil had you by the legs on judg[e]ment day." 
Finally, we classified RD as involving an inferable antecedent, if the unexpressed antecedent formed part of the physical environment (23)a or of the common ground (23)b:

a. XEIXA garbellant blat. [...] XEIXA: Tant se XEIXA sifting wheat so myself me'n dóna que quedi net com brut, aquest to-me-of.it matter.3SG that gets clean as dirty this blat.

wheat

"XEIXA is discovered sifting wheat. XEIXA. What does it matter whether the wheat's clean or whether it ain't clean?" [Guimerà: p. 163]

b. -Escolta Frederic. Tinc trenta-un anys, saps?

Listen Frederic have.1SG thirty-one years know.2SG Vull dir que ja sóc prou gran i no want.1SG say that already am enough old and not t'has de ficar per a res en els meus to.you-have.2SG to get for a nothing in the.PL my.PL negocis. Jo no t'ho pregunto, el que fas, business.PL I not to.you-it ask.1SG the that do.2SG ni què menges, ni si perds o guanyes neither what eat.2SG, neither whether lose.2SG or win.2SG jugant, ni si vas a demanar diners a gambling, neither whether go.2SG to ask money to la teva sogra... the.FEM your.FEM mother-in-law..." [Sagarra: p. 126] "-Listen, Frederic. I am thirty-one, ok? I mean, I am old enough, so you don't have to poke your nose into my business. I don't ask you what you do, what you eat, whether you lose or win at gambling, whether you ask your mother-in-law for money..." [Sagarra: p. 126] 


\section{Polarity}

When considering the polarity of sentences, we began with the classical distinction between positive and negative polarity, and then we considered the presence of any positive or negative morphological marker. As a rule, Catalan lacks any particle for positive unmarked sentences and adds the negative adverb no 'not' in a pre-verbal position next to the verbal head in unmarked negative ones:

$$
\begin{aligned}
& \text { a. La Maria plora. } \\
& \text { the.FEM Mary cries } \\
& \text { 'Mary is crying.' } \\
& \text { b. La Maria no plora. } \\
& \text { the.FEM Mary not cries } \\
& \text { 'Mary is not crying.' }
\end{aligned}
$$

Abstracting from the fact that the positive is unmarked with respect to the negative, the first case was coded as POSITIVE-UNMARKED, and the second as NEGATIVE-UNMARKED.

Moreover, we do have cases where the positive polarity is reinforced by means of a specific item (e.g. si que 'indeed', ja 'indeed' and prou 'indeed'), which results in an emphatic assertion, similar to English indeed or emphatic do-support:

$$
\begin{aligned}
& \text { MANELIC: Bon mosso. Si vol dir tirar dret amb } \\
& \text { good fellow if wants say throw straight with } \\
& \text { la fona i botre com els isards cingles avall i } \\
& \text { the.FEM sling and leap like the.PL deers cliffs down and } \\
& \text { cingles amunt, i dur la Marta a coll-i-bé, saltant les } \\
& \text { cliffs up and carry the Marta to shoulders jumping the.FEM }
\end{aligned}
$$


passeres de Riublanc quan les neus se fonen, oidà, wades of Riublanc when the.FEM.PL snow.PL self melt, why sí que en sóc, de bon mosso. yes that of.it am of good fellow "MANELICH. Well, there's nothin' to laugh at. If to be a fine fellow means to throw farther with the sling than anybody, to leap from cliff to cliff like the goats, to carry Marta on my shoulder through the deep places in the river when the snow comes down, then I am a fine fellow!" [Guimerà: p. 176]

These cases were coded as POSITIVE-MARKED.

Finally, one must note that negation in Catalan can be expressed redundantly, that is by means of different elements besides the negative adverb no (see Espinal (2002, sec. 24.2) and references cited therein). One startling case is the negative reinforcer pas:

a. ANTÒNIA (cridant): Marta! Marta! PEPA (cridant): Marta Marta PEPA screaming

Som les Perdigones. Surt! are.1PL the Perdigones come.out.2SG

"ANTONIA [calling out]. Here we are! Come out, woman!"

b. XEIXA: No sortirà pas, la Marta. [...] not come.out.will.3SG not the Marta "XEIXA: I don't think she'll come...." [Guimerà: p. 163-4]

Another apparent instance of negative reinforcement is the combination of the negative marker with a negative polarity item:

$$
\begin{aligned}
& \text { [MARTA:] Si no sóc ningú, jo, ningú;... } \\
& \text { if not am nobody I nobody } \\
& \text { "[MARTA:] I'm nobody! [...]" [Guimerà: 169] }
\end{aligned}
$$


These cases were coded as NEGATIVE-MARKED.

Hence, we obtained the following typology:

- positive

- unmarked (24)a

- marked (25)

- negative

- unmarked (24)b

- marked (26)-(27)

\section{Results}

\subsection{Frequencies}

We identified 257 occurrences of RD in our corpus, which were distributed in the following way, concerning the variables studied.

Firstly, regarding discourse function, activation and continuation RDs were distributed in an almost perfect half-half: a 51\% for activation (131 occurrences) and a $49 \%$ for continuation (126 occurrences). The chi-square test showed no significant differences between the three texts neither at the 0.05 nor at the 0.001 level: for two degrees of freedom, $\chi^{2}$ was 3.8627 , whereas the expected values were 5.99 at the 0.05 level and 13.82 at the 0.001 level. These data contrasted with previous studies, like Villalba $(2011,1955)$, where preference was shown for activation (59\%) versus continuation (36\%). 
Secondly, when the distance of the antecedent was considered, local antecedents amounted almost half the occurrences (126 occurrences, 49\%), followed by inferable (82 occurrences, $32 \%$ ) and non-local antecedents (49 occurrences, 19\%). The chi-square test showed no significant differences between the three texts neither at the 0.05 nor at the 0.001 level: for four degrees of freedom, $\chi^{2}$ was 5.5228, whereas the expected values were 9.49 at the 0.05 level and 18.47 at the 0.001 level. The results matched quite exactly the data in Villalba (2011, 1955), who reports a $41 \%$ for inferable, $40 \%$ for local, and $19 \%$ for non-local antecedents.

Finally, when polarity was considered (a variable not studied in (Villalba 2011)), the distribution was balanced between positive and negative categories, with a slight preference for the former: $57 \%$ and $43 \%$, respectively. This was quite unexpected a priori, for even though no studies exist for Catalan, corpus research on English points toward a much stronger preference for affirmative sentences (the unmarked member of the opposition). For instance, Givón $(1995,43)$ reports that in a sample of 162 sentences of a fiction text, affirmative sentences amounted an $88 \%$ vs. the $12 \%$ of negative ones. Although studies like Tottie $(1991,17)$ or Biber et al. $(1999,159)$ corrected this $12 \%$ for spoken English to a $27.6 \%$ and $22.2 \%$, respectively, these figures were still far from the above mentioned $43 \%$. The chi-square test showed no significant differences between the three texts neither at the 0.05 nor at the 0.001 level: or two degrees of freedom, $\chi^{2}$ was 3.0201, whereas the expected values were 5.99 at the 0.05 level and 13.82 at the 0.001 level.

Among each polarity category, one could consider a finer-grained distri- 
bution regarding the presence of a reinforcer. Hence, unmarked cases greatly outnumbered marked ones both in positive (71\% vs. 29\%) and negative cases (67\% vs. $33 \%)$ in a similar proportion. We summarize the data in Table 1.

\begin{tabular}{c|cc|cc|} 
& \multicolumn{2}{|c|}{ positive } & \multicolumn{2}{c|}{ negative } \\
\hline & $\#$ & $\%$ & $\#$ & $\%$ \\
\hline \hline unmarked & 103 & 71 & 74 & 67 \\
marked & 43 & 29 & 37 & 33 \\
\hline total & 146 & 100 & 111 & 100
\end{tabular}

Table 1: Frequencies of the polarity variable.

As for the reinforcers, among positive ones the most common was $j a$ 'already' (72\%), followed at a great distance by si que 'indeed' (16\%) (see Table 2). Among negatives, the most frequent was pas (57\%), followed by the NPI res 'nothing' (24\%) (see Table 3).

\begin{tabular}{l|rr|} 
& $\#$ & $\%$ \\
\hline ja 'already' & $\mathbf{3 1}$ & $\mathbf{7 2}$ \\
sí que 'indeed' & 7 & 16 \\
prou 'indeed' & 2 & 5 \\
també 'also' & 2 & 5 \\
pla bé 'indeed' & 1 & 2 \\
\hline total & 43 & 100
\end{tabular}

Table 2: Frequencies of positive reinforcers.

\begin{tabular}{l|rr|} 
& total & $\%$ \\
\hline pas 'NEG' & $\mathbf{2 1}$ & $\mathbf{5 7}$ \\
res 'nothing' & 9 & 24 \\
mai 'never' & 5 & 13 \\
gaire 'any' & 1 & 3 \\
tampoc 'neither' & 1 & 3 \\
\hline total & 37 & 99.62
\end{tabular}

Table 3: Frequencies of negative reinforcers. 


\subsection{Dependencies across variables}

When the interaction between variables was considered some generalisations followed. In the case of discourse function and distance, as one would expect, all cases of continuation were local; instead, activation RDs were most frequently inferable (63\%), and less commonly non-local (37\%) (see Table 4).

\begin{tabular}{c|cc|cc|cc} 
& \multicolumn{2}{|c|}{ local RD } & \multicolumn{2}{|c|}{ non-local RD } & \multicolumn{2}{|c}{ inferable RD } \\
& $\#$ & $\%$ & $\#$ & $\%$ & $\#$ & $\%$ \\
\hline \hline activation & 0 & 0 & 49 & 37 & 82 & 63 \\
continuation & 126 & 100 & 0 & 0 & 0 & 0 \\
\hline
\end{tabular}

Table 4: Discourse function regarding distance.

This strong dependency made the chi-square test non-significant: $\chi^{2}$ matched the number of cases (257), and p-value was $<0.0001$.

When we considered discourse function regarding polarity (see Table 5), one could easily appreciate the shift in the correlation between polarity and discourse function of the dislocate: whereas the positive cases favoured activation ( $55 \%$ and $65 \%$ for unmarked and marked cases, respectively), negative polarity favoured continuation in a similar rate $(57 \%$ and $62 \%$ for unmarked and marked cases, respectively).

\begin{tabular}{c|cccc|ccccc|} 
& \multicolumn{4}{|c|}{ positive } & \multicolumn{4}{c|}{ negative } \\
& unmarked & marked & \multicolumn{3}{c|}{ unmarked } & marked \\
& $\#$ & $\%$ & $\#$ & $\%$ & $\#$ & $\%$ & $\#$ & $\%$ \\
\hline activation & $\mathbf{5 4}$ & $\mathbf{5 5}$ & $\mathbf{3 1}$ & $\mathbf{6 5}$ & 32 & 43 & 14 & 38 \\
continuation & 44 & 45 & 17 & 35 & $\mathbf{4 2}$ & $\mathbf{5 7}$ & $\mathbf{2 3}$ & $\mathbf{6 2}$ \\
\hline total & 98 & 100 & 48 & 100 & 74 & 100 & 37 & 100
\end{tabular}

Table 5: Discourse function regarding polarity.

In this case, the chi-square test showed a significant difference at the 
0.005 level: for one degree of freedom, $\chi^{2}$ was 7.1029 , clearly higher than the expected value (3.84).

As for the reinforcers involved, a clear specialization was found at least for the most frequent instances. The commonest positive reinforcers $j a$ 'already' (72\%) and si que 'indeed' (16\%) showed a strong tendency toward activation (74\% vs. $26 \%$ ) and continuation (14\% vs. $86 \%$ ), respectively (see Table 6). Among negatives, the most frequent was pas (57\%), which showed a strong preference for the continuation function: $75 \%$. The NPI res 'nothing' (24\% of the cases), showed the same preference, but less robustly: 56\% (see Table $6)$.

\begin{tabular}{c|rr|rr|} 
& \multicolumn{2}{|c|}{ activation } & \multicolumn{2}{c|}{ continuation } \\
\hline & $\#$ & $\%$ & $\#$ & $\%$ \\
\hline ja 'already' & $\mathbf{2 3}$ & $\mathbf{7 4}$ & 8 & 25 \\
sí que 'indeed' & 1 & 14 & $\mathbf{6}$ & $\mathbf{8 6}$ \\
prou 'indeed' & 1 & 50 & 1 & 50 \\
també 'also' & 2 & 100 & 0 & 0 \\
pla bé 'indeed' & 1 & 100 & 0 & 0 \\
\hline pas 'NEG' & 7 & 25 & $\mathbf{1 4}$ & $\mathbf{7 5}$ \\
res 'nothing' & 4 & 44 & $\mathbf{5}$ & $\mathbf{5 6}$ \\
mai 'never' & 1 & 20 & 4 & 80 \\
gaire 'any' & 1 & 100 & 0 & 0 \\
tampoc 'neither' & 1 & 100 & 0 & 0
\end{tabular}

Table 6: Reinforcers regarding function.

Finally, when we considered the relations between polarity and distance (see Table 7), local antecedents were the most common category, except for positive marked cases, where inferable antecedents take precedence by more than 10 points (35\% for local antecedents vs. $46 \%$ for inferable antecedents). Moreover, even though local antecedents take clear preference over non-local ones in both positive and negative categories, it is remarkable that they do it 
in a more outstanding way in the latter: whereas the difference between local and non-local antecedents amounts 20 points for unmarked positives and 17 points for marked positives, it boosts to 39 points for unmarked negatives, and to 54 for marked negatives.

\begin{tabular}{|c|c|c|c|c|c|c|c|c|}
\hline & \multicolumn{4}{|c|}{ positive } & \multicolumn{4}{|c|}{ negative } \\
\hline & un & arked & & ked & unı & arked & $\mathrm{ma}$ & ked \\
\hline & $\#$ & $\%$ & $\#$ & $\%$ & $\#$ & $\%$ & \# & $\%$ \\
\hline local & 44 & 45 & 17 & 35 & 42 & 57 & 23 & 62 \\
\hline non-local & 24 & 24 & 9 & 19 & 13 & 17 & 3 & 8 \\
\hline inferable & 30 & 31 & 22 & 46 & 19 & 26 & 11 & 30 \\
\hline total & 98 & 100 & 48 & 100 & 74 & 100 & 37 & 100 \\
\hline
\end{tabular}

Table 7: Polarity regarding distance.

In this case, the chi-square test also showed a significant difference at the 0.005 level: for two degrees of freedom, $\chi^{2}$ was 7.2962 , higher than the expected value (5.99).

When we considered the relation between distance and reinforcers, we found the same pattern that affected function and reinforcers, which was unsurprising, for we confirmed a significant dependence between the function and the distance variables. The most common positive reinforcer $j a$ 'already' $(72 \%)$ showed a clear tendency toward inferable antecedents (55\%), whereas sí que 'indeed' (16\%) showed a extremely strong tendency toward local antecedents (86\%) (see Table 8). Among negatives, the most frequent were pas (57\%) and the negative polarity item res 'nothing' (24\% of the cases), and both showed the same preference toward local antecedents: $67 \%$ and 55\%, respectively (see Table 8). 


\begin{tabular}{c|rr|rr|rr|} 
& \multicolumn{2}{|c|}{ local } & \multicolumn{2}{c|}{ non-local } & \multicolumn{2}{r|}{ inferable } \\
\hline & $\#$ & $\%$ & $\#$ & $\%$ & $\#$ & $\%$ \\
\hline \hline ja & 8 & 26 & 6 & 19 & $\mathbf{1 7}$ & $\mathbf{5 5}$ \\
sí que & $\mathbf{6}$ & $\mathbf{8 6}$ & 0 & 0 & 1 & 14 \\
prou & 1 & 50 & 0 & 0 & 1 & 50 \\
també & 2 & 100 & 0 & 0 & 0 & 0 \\
pla bé & 0 & 0 & 0 & 0 & 1 & 100 \\
\hline \hline pas & $\mathbf{1 4}$ & $\mathbf{6 7}$ & 2 & 9 & 5 & 24 \\
res & $\mathbf{5}$ & $\mathbf{5 6}$ & 1 & 11 & 3 & 33 \\
mai & 4 & 80 & 0 & 0 & 1 & 20 \\
gaire & 0 & 0 & 0 & 0 & 1 & 100 \\
tampoc & 0 & 0 & 0 & 0 & 1 & 100
\end{tabular}

Table 8: Reinforcers regarding distance

\section{Discussion}

Our data show that Catalan RD is to a high extent an extremely local process: $49 \%$ of the occurrences involved a local antecedent, whereas RD with nonlocal antecedents amounted a 19\%. These findings argue against (Grosz and Ziv 1998, 301-2) claims that RD is essentially a non-local process, for, leaving aside the case of attributive $\mathrm{RD}$, the instances of $\mathrm{RD}$ with a local antecedent can always be more effectively substituted by pronominalisation (i.e. dropping of the dislocate).

The pervasive presence of continuing RD (about half the cases; see 4.1) suggests that it cannot be considered an optional operation in any event, which raises again the issue of its informational role.

In the next section we will discuss several examples which show that RDs can carry out several types of discourse function. First, a considerable number of RDs are tails à la Vallduví: the RD indicates that the information contained in a file card needs to be substituted. However, the notion of tail 
needs to be re-defined to cover the full range of uses of RDs in Catalan: it does not just serve to mark cases of information substitution, but also information addition. Moreover, we propose that the expression of polarity is the main correlate of a tailful instruction. Finally, we will also discuss examples in which the RD clearly has an activation role.

In order to illustrate the discourse function of $\mathrm{RD}$, we will use the file card metaphor and associate each discourse referent with a file card. Our notation is loosely based on File Change Semantics (Heim 1983). ${ }^{6}$

\subsection{Information substitution}

We first consider examples of RDs in which their function matches the concept of tail, as defined by Vallduví: that is, the information in focus modifies some information that had already been added into a file card. We already discussed an example of this type in (9) and (10), repeated below for convenience.

a. I gosaries? Contra el teu amo?

and dare.would.2SG against the your master

"What - to the master?"

b. Ja no m'ho és, l'amo: ni mai que ho already not to.me-it is the-master neither never that it hagués sigut. had.would been

"He ain't my master, and I wish he never had been." [Guimerà:

\footnotetext{
${ }^{6}$ File Change Semantics, together with Discourse Representation Theory (Kamp and Reyle 1993), is one of the main theories that go beyond the semantic-pragmatic analysis of isolated sentences and aim at building a semantic-pragmatic representation for an entire discourse, giving a general treatment for indefinite and definite NPs and anaphora possibilities in discourse.
} 
p. 181]

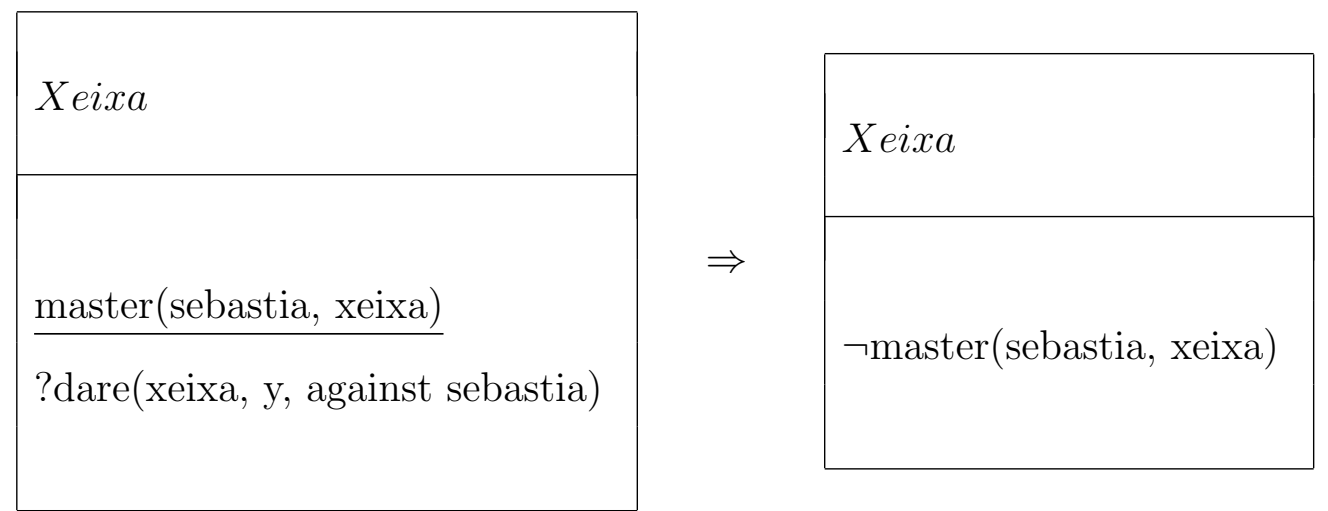

As mentioned, the RD contains the negation of previously presupposed material, so that this presupposition gets substituted by new information (i.e., 'Sebastià is not my master anymore'). We would like to argue it is not coincidence that $65 \%$ (82 out of 126) of continuation RDs display either negative polarity or marked positive polarity. As argued by Givón $(1979,107)$, "negative assertions are used in language in contexts where the corresponding affirmative has been mentioned, deemed likely, or where the speaker assumes that the hearer -erroneously- holds to a belief in the truth of that affirmative." Thus, such a high proportion of marked polarity (and particularly negative polarity) is explained by the fact that the $\mathrm{RD}$ is substituting previously added information corresponding to the affirmative assertion.

A similar example is shown in (30). In this case, the content of an imperative is negated by a subsequent assertion, structured as an RD. ${ }^{7}$

a. ANTÒNIA (cridant): Marta! Marta! PEPA (cridant):

Marta Marta PEPA screaming

Som les Perdigones. Surt!

are.1PL the Perdigones come.out

\footnotetext{
${ }^{7}$ The symbol $\square$ represents the necessity operator in modal logic.
} 
"ANTONIA [calling out]. Here we are! Come out, woman!"

b. XEIXA: No sortirà pas, la Marta. [...]

not come.out.will.3SG not the Marta

"XEIXA: I don't think she'll come..." [Guimerà: p. 163-4]

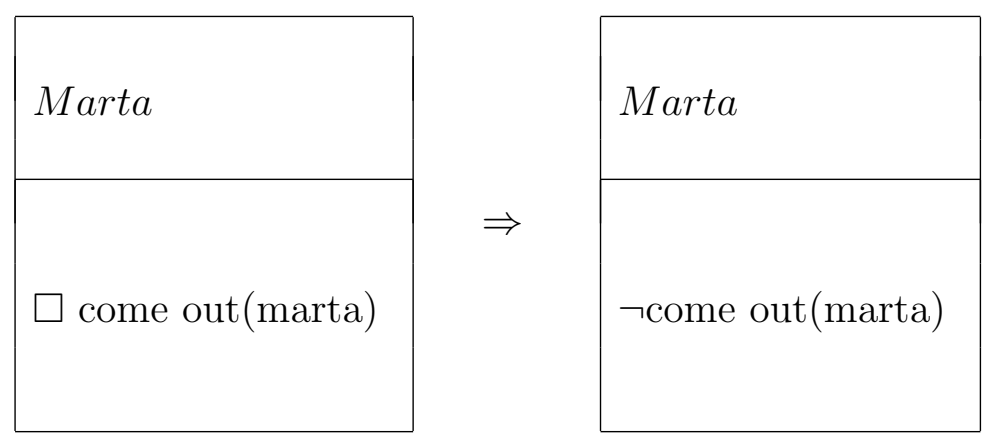

This example could be considered as a case of free variation between the sentence with the dislocated phrase and the sentence without the dislocated phrase (31). The difference between the two is that in the former there is an explicit tailful instruction to substitute information, while in the latter there is no such explicit instruction. The end results would be the same in the two cases, but the fact that the RD explicitly encodes a substitution instruction makes them the preferred option in contexts in which the speaker is denying a previous utterance.

$$
\begin{aligned}
& \text { No sortirà pas. } \\
& \text { not come.out.will.3SG not } \\
& \text { "She won't come." }
\end{aligned}
$$

Finally, consider (32). This example is similar to the ones before but it shows that the substituted information ("I will make you a jacket") can be retrieved from an embedded position, inside a propositional attitude verb, 
such as think.

(32) a. Doncs pensava en fer-te una samarra en acabant aquesta. No de color d'esca, no; de blauet, i amb un vions vermells que t'escauran més!. . .

"I was thinkin' I would make you a jacket, when I finish this one, but not this color; it must be blue and pink; you'll look so nice in it!"

b. No me la facis la samarra, Nuri. not to.me her make.2SG the.FEM jacket Nuri "No, don't make me the jacket, Nuri." [Guimerà: p. 187]

C.

Nuri

(1)
Jacket

blue(jacket)
stripped(jacket)

d.

\begin{tabular}{|l|}
\hline Nuri \\
\hline$\neg$ make(nuri, jacket) \\
\hline
\end{tabular}




\subsection{Special information addition}

This section includes some examples which show that the definition of tail should be broadened in order to encompass a larger range of naturallyoccurring examples. Namely, we show that what is crucial is not that the focal part of the RD substitutes previous information, but that the added information had been present in some way in discourse. That is, by means of an RD construction, an open proposition from the previous discourse is recovered and used again. This open proposition may have a missing argument, may be modified by adjuncts or operators, such as negation or may be embedded under a propositional attitude verb, which is not expected under an account of plain substitution.

Let us consider first examples in which there is only one relevant file, where all the information is updated and where a tail does not replace an old entry for a new (updated) entry, but it adds information to a previous entry. Such an example is shown in (33). No information is erased and replaced by new information, but further information is added to an existing entry; in this particular case, information about degree. That is, first the character says that Sebastià was a wicked man, and later she says that now he is even wicker (see the degree particle in italics in the example).

(33) Mal home! I prou que es veia que ho eres! I ara wicked man and enough that self sees that it were.2SG and now ho ets més, aturmentant-me, un mal home! it are,2SG more tormenting-me a wicked man "Wicked man! I could you see you were a wicked man and now you are more wicked tormenting me!" [Guimerà: p. 185] 


\begin{tabular}{|c|c|c|}
\hline Sebastia & & Sebastia \\
\hline wicked(sebastia) & $\Rightarrow$ & wicked(sebastia, degree(x)) \\
\hline
\end{tabular}

(34) is a similar example in which the previous entry is augmented with temporal information and, moreover, embedded into a propositional attitude verb, such as want. Examples like the previous two explain the proportion of degree and temporal markers that appear in RDs: 21 utterances contained a temporal adverb $(8.17 \%)$ and 20 included a degree particle $(7.78 \%)$. We suspect that these proportions of temporal and degree markers in RD constructions are higher than in other constructions or in general text, but we leave this issue for future research.

[...] com a home i com a fera, que ho sóc i que ho like as man and like as beast that it am and that it vull ser sempre home i fera... want.1SG be always man and beast "I am a man and a beast, and I will always be..." [Guimerà: p. 204]

\begin{tabular}{|l|l|}
\hline Manelic & Manelic \\
\hline man(manelic) \\
beast(manelic)
\end{tabular}$\Rightarrow \quad \begin{aligned} & \text { want(manelic, man, always) } \\
& \text { want(manelic, beast, always) }\end{aligned}$


(35) shows another example in which we need to make use of an open proposition in order to embed it into a conditional construction. First, the speaker asserts that she must be very bad. Then, the proposition bad(marta) is negated, modified by a degree adjunct and embedded into the antecedent of a counterfactual conditional. Again, what we observe is that the RD is not substituting previously stored information, but using part of a previously stored proposition in order to update new information.

$$
\begin{gathered}
\text { [MARTA:] Que en dec ser de dolenta jo! Dolenta d'aquí } \\
\text { that of.it must.1SG be of bad I bad of-here } \\
\text { ben endintre! Perquè si no ho fos tant, de dolenta, }
\end{gathered}
$$
well into because if not it were.1SG so of bad tindria més esperit jo. had.would.1SG more spirit I

"I'm bad! If I were not bad, I would have run away long ago." [Guimerà: p. 169]

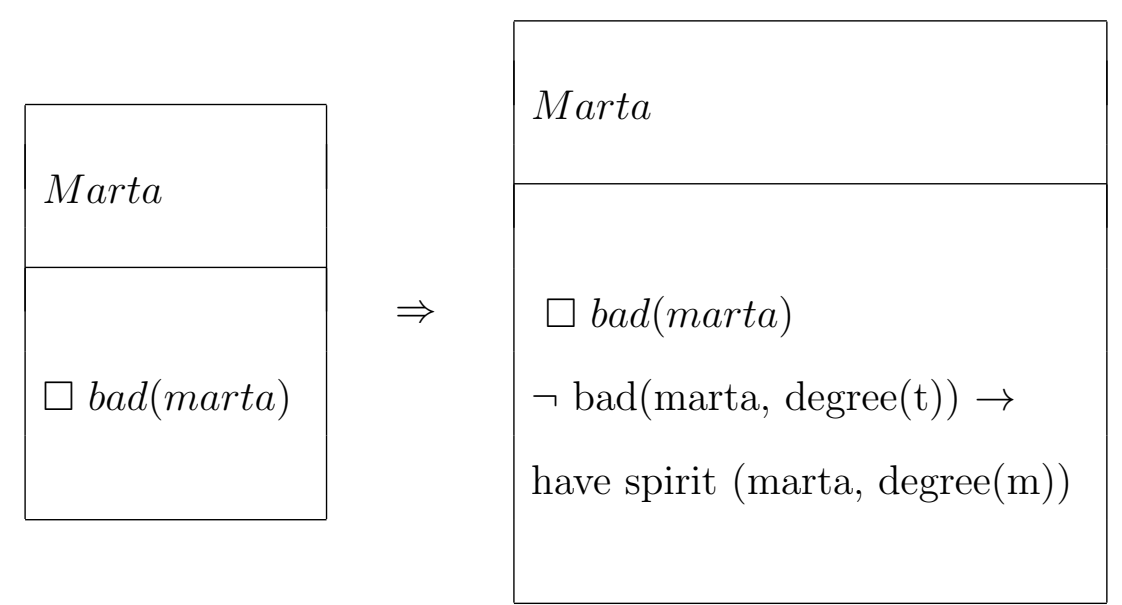

Let us turn now to examples in which more than one file play a role in the discourse. (36) shows an example in which an open proposition previously mentioned is added in different files. First, some information is added to Marta's file. Then, the open proposition hate $(x, y)$ is negated and the the- 
matic roles changed and added in Nuri's (the speaker) file. This is clearly not a case of tail in its narrow sense, but it can be included into the more general notion of addition tail.

[NURI:] I del dia que t'hi vas casar que and of-the day that to.you-there PAST.1SG marry that

em té una malícia!... Jo no n'hi tinc pas de to.me has a badness... I not of.it-there have.1SG not of malícia an ella.

badness to her

"Since she married you, she hates me!... I don’t hate her." [Guimerà: p. 187],
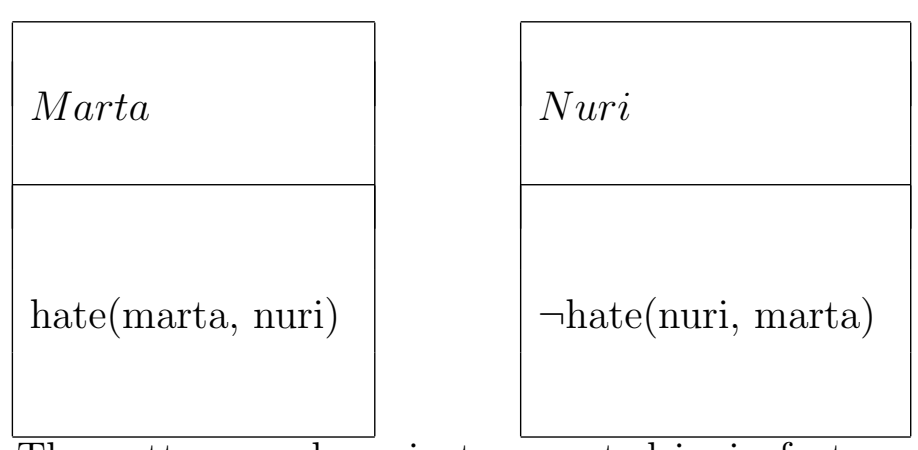

The pattern we have just presented is, in fact, quite common. That is, the RD may serve to update some previously mentioned proposition in a different file card (that is, attribute previously mentioned information to a new referent). (37) shows a further example. First the speaker is entering information into x's file card, which presupposes that $\mathrm{x}$ is married. Next, this open proposition $(\operatorname{married}(x))$ is added to another file card (corresponding to the speaker himself) with negation on top.

$$
\begin{aligned}
& \text { Ha d'enterrar la seva dona -féu el jueu amb } \\
& \text { has of-bury the.FEM your.FEM wife said.3SG the Jew with } \\
& \text { aire sorneguer-. Jo no en tinc pas, de dona. } \\
& \text { air slyly } \quad \text { I not of.it have.1SG not of wife }
\end{aligned}
$$


"You got to bury your wife," the Jew needled slyly. "I ain’t got no wife." [Himes: p. 23]

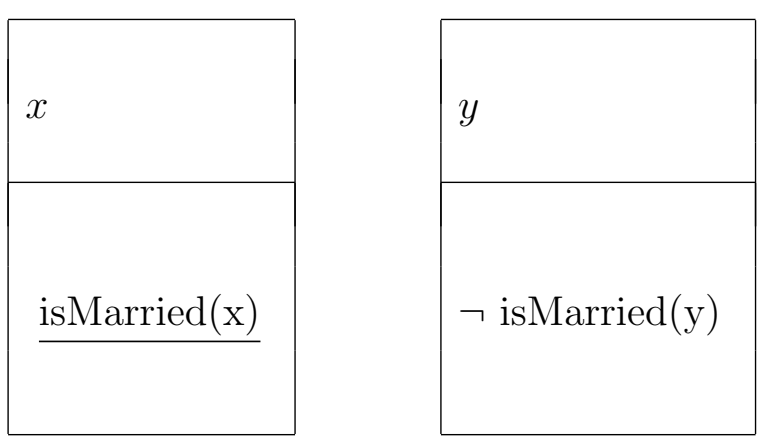

To sum up, in the section, we have shown that a broader definition of tail is called for. Using this broader definition, we can account for a high percentage of occurrences of RDs in Catalan.

\subsection{Activation RD}

Finally, we argue that not all RDs convey a tail instruction, even understanding tail in the broadest sense. Consider, for example, (38).

(38) a. JOSEP: L'ermità, a l'anar ahir cap a les Punxales, s'aturà a beure al mas Perruca, i tot satisfet ho va contar a l'hereu Perruca, i el Perruca an a mi. Oh! I que ho va contant a tothom d'aquestos volts! I que aquí no s'ho pensen, i es trobaran que vindrà una gentada al casament.

"When Tomàs was on his way to the mountain, he stopped at Peluca's house to take a drink, and told him all about it: Peluca has told everybody; and when they least expect it, they'll find the whole town at the wedding." 
b. PEPA: I quin paper més lleig que fa, l'ermità! and which role more ugly that makes the-hermit

Ecs!

eww

"Tomàs acted so rudely!" [XV\&LM] [Guimerà: p. 168]

In this dialogue, the first speaker talks about three different discourse referents, as shown in (39). First, the speaker talks about Tomàs, the hermit, and adds some information to his card. Then, the topic is switched to Perruca and, finally, to the "people from around here".

\begin{tabular}{|l|}
\hline Tomas \\
\hline go(Tomas, mountain) \\
stop(Tomas, Perruca's_house) \\
explain(Tomas, y, Perruca) \\
\hline
\end{tabular}

Perruca

explain(Perruca, y, speaker) explain(Perruca, y, everyone)

People from here

$\neg$ know(people from here, come(many people, wedding)) 
When the other speaker intervenes, she wants to refer back to the first of these three referents, Tomàs, and she does so by means of an RD (38). Note that in this case it cannot be argued that the RD functions as a tail: no information is substituted, no information previously mentioned is added to any file. It is just a simple instance of information addition (see (40)) to a referent which was not active any more.

\begin{tabular}{|l|}
\hline Tomas \\
go(Tomas, mountain) \\
stop(Tomas, Perruca's_house) \\
explain(Tomas, y, Perruca) \\
rude(Tomas) \\
\end{tabular}

(41) shows another example of activation topic. The character Manelic has been obsessing over finding the identity of the man who entered his home. This man, however, has not been mentioned over a long stretch of discourse. In order to re-activate this topic, an RD is used.

$$
\text { [MANELIC:] Mes aquella claror no va venir }
$$
but that.FEM lightness not PAST.3SG come tota sola, i jo vui saber-ho qui era aquell all.FEM alone.FEM and I want.1SG know-it who was that home, per matar-lo. man to kill-him "That light, back of the curtain, a man was carryin' it! What I 
want to know is who he was. I'll kill him - and go back up there." [Guimerà: p. 188]

To finish this section, consider the example in (42), in which the dislocated referent had never been explicitly mentioned but was present in the utterance context. It is impossible to maintain that in this case the RD is acting as a tail, since nothing had been added to the file card of the referent, but the $\mathrm{RD}$ is a way of making accessible a contextually salient referent.

XEIXA garbellant blat. [...] XEIXA: Tant se me'n
XEIXA sifting wheat so myself to-me-of.it
dóna que quedi net com brut, aquest blat.
matter.3SG that gets clean as dirty this wheat
"XEIXA is discovered sifting wheat. XEIXA. What does it matter
whether the wheat's clean or whether it ain't clean?" [Guimerà: p.
163]

\section{Conclusions}

Right dislocation in Catalan is a highly local phenomenon (contra Ziv (1994), Grosz and Ziv (1998)), favouring local and inferable antecedents. We have shown, on the basis of a corpus study, that most RDs are tails, although the notion of tail needs be redefined: it is not just a matter of substitution, but also the negation of a presupposition, or the contradiction of part of the interlocutor common knowledge or addition of information regarding polarity, tense, aspect or degree. Moreover, we have argued that some RDs are not tails, but serve to activate a previously introduced referent or a referent 
inferable from the context (contra Escandell-Vidal (2009)). One construction several functions, as discussed by Prince (1997) for left-dislocations in English.

\section{References}

Ariel, M.: 1991, The function of accessibility in a theory of grammar, Journal of Pragmatics 16, 443 - 463.

Ashby, W.: 1988, The syntax, pragmatics, and sociolinguistics of left- and right-dislocation in French, Lingua 75, 203-229.

Asher, N. and Lascarides, A.: 2003, Logics of Conversation, Cambridge University Press, Cambridge.

Biber, D., Johansson, S., Leech, G., Conrad, S. and Finegan, E. (eds): 1999, The Longman Grammar of Spoken and Written English, Longman, London.

Brunetti, L.: 2009, On links and tails in Italian, Lingua 119(5), 756-781.

Chafe, W. L.: 1976, Giveness, contrastiveness, definiteness, subjects, topics, and point of view, in C. Li (ed.), Subject and Topic, Academic Press, New York, pp. 25-55.

Escandell-Vidal, V.: 2009, Differential object marking and topicality The case of Balearic Catalan, Studies in Language 33(4), 832 - 885. 
Espinal, M. T.: 2002, La negació, in J. Solà, M. R. Lloret, J. Mascaró and M. P. Saldanya (eds), Gramàtica del català contemporani, Vol. 3, Empúries, Barcelona, pp. 2727-2797.

Geluykens, R.: 1987, Tails (right-dislocations) as a repair mechanism in English conversation, in J. Nuyts and G. de Schutter (eds), Getting One's Word into Line, Foris, Dordrecht, pp. 119-129.

Givón, T.: 1979, On Understanding Grammar, Academic Press, New York.

Givón, T.: 1983, Topic continuity in discourse: an introduction, in T. Givòn (ed.), Topic Continuity in Discourse: A Quantitative Cross-Language Study, John Benjamins, Amsterdam/Philadelphia, pp. 1-42.

Givón, T.: 1993, English Grammar: A Function-Based Introduction, John Benjamins, Amsterdam/Philadelphia.

Givón, T.: 1995, Functionalism and Grammar, John Benjamins, Amsterdam/Philadelphia.

Grosz, B. and Ziv, Y.: 1998, Centering, global focus, and right dislocation, in M. Walker, A. Joshi and E. Prince (eds), Centering in Discourse, Oxford University Press, Oxford, pp. 293-307.

Gundel, J. K., Hedberg, N. and Zacharski, R.: 1993, Cognitive Status and the Form of Referring Expressions in Discourse, Language 69(2), 274 307. 
Heim, I.: 1983, File change semantics and the familiarity theory of definiteness, in C. Schwarze and A. von Stechow (eds), Meaning, Use and Interpretation of Language, De Gruyter, Berlin, pp. 164-178.

Kamp, H. and Reyle, U.: 1993, From Discourse to Logic: Introduction to Modeltheoretic Semantics of Natural Language, Formal Logic and Discourse Representation Theory, Kluwer Academic Publishers, London, Boston, Dordrecht. Studies in Linguistics and Philosophy, Volume 42.

Lambrecht, K.: 1981, Topic, Antitopic and Verb-Agreement in Non-Standard French, John Benjamins, Amsterdam/Philadelphia.

Lambrecht, K.: 1994, Information Structure and Sentence Form. Topic, Focus, and the Mental Representation of Discourse Referents, Cambridge University Press, Cambridge.

Mayol, L.: 2006, The discourse function of right-dislocation in Catalan, Proceedings of the Sprik Conference 2006: Explicit and Implicit Information in Text. Information Structure across Languages, pp. 35-40.

Mayol, L.: 2007, Right-dislocation in Catalan: Its discourse function and counterparts in English, Languages in Contrast 7, 203-220.

Prince, E.: 1981, Toward a taxonomy of given-new information, in P. Cole (ed.), Radical Pragmatics, Academic Press, New York, pp. 223-255.

Prince, E.: 1997, On the functions of left-dislocation in english discourse, in A. Kamio (ed.), Directions in Functional Linguistics, John Benjamins, Philadelphia/Amsterdam, pp. 117-144. 
Roberts, C.: 1995, Information structure in discourse: Toward a unified theory of formal pragmatics. unpublished ms. Ohio State University.

Tottie, G.: 1991, Negation in English speech and writing: a study in variation, Academic Press, New York.

Valiouli, M.: 1994, Anaphora, agreement, and right dislocations in Greek, Journal of Semantics 11, 55-82.

Vallduví, E.: 1992, The Informational Component, Garland, New York.

Vallduví, E.: 2002, L'oració com a unitat informativa, in J. Solà, M. R. Lloret, J. Mascaró and M. Pérez Saldanya (eds), Gramàtica del català contemporani, Vol. 2, Empúries, Barcelona, pp. 1221-1279.

Villalba, X.: 2009, The Syntax and Semantics of Dislocations in Catalan. A Study on Asymmetric Syntax at the Peripheries of Sentence, Lambert Academic Publishing, Köln.

Villalba, X.: 2011, A quantitative comparative study of right-dislocation in Catalan and Spanish, Journal of Pragmatics 43(7), 1946-1961.

Ziv, Y.: 1994, Left and right dislocations: Discourse functions and anaphora, Journal of Pragmatics 22, 629-664. 